\title{
OCCUPATIONAL STRESS AND DISSATISFACTION WITH QUALITY OF WORK LIFE IN NURSING
}

\author{
Bruno Del Sarto Azevedoํ. Adriana Alves Nery², Jefferson Paixão Cardoso ${ }^{3}$
}

\footnotetext{
${ }^{1}$ M.Sc. in Nursing and Health. Jequié, Bahia, Brazil. E-mail: brunodelsarto@outlook.com

${ }^{2}$ Ph.D. in Public Health Nursing. Professor, Health Department II and Graduate Program in Nursing and Health, Universidade Estadual do Sudoeste da Bahia (UESB). Jequié, Bahia, Brazil. E-mail: aanery@gmail.com

${ }^{3}$ doctoral student, Collective Health Institute, Universidade Federal da Bahia. Professor, Department of Health II, UESB, Jequié, Bahia, Brazil. E-mail: jpcardoso@uesb.edu.br
}

\section{ABSTRACT}

Objective: to analyze the association between occupational stress, quality of work life and associated factors among nursing workers.

Method: 309 nursing workers of a public general hospital participated in this cross-sectional study. The Total Quality of Work Life and the Job Stress Scale instruments were used to evaluate the quality of work life and occupational stress, respectively.

Results: associations were estimated using Poisson regression analysis combined with robust variance. We found association between dissatisfaction with quality of work life and smoking ( $\mathrm{PR}=1.53$; $95 \% \mathrm{CI}$ : 1.02-2.31), work at the care units for highly dependent or critically ill patients ( $\mathrm{PR}=2.47 ; 95 \% \mathrm{CI}: 1.18-5.19)$, low social support at work ( $\mathrm{PR}=1.76 ; 95 \% \mathrm{CI}: 1.29-2.40)$ and the quadrants of the demand-control model "active job" (PR=1.74; 95\% CI: 1.04-2.92) and "high-strain job" (PR=2.54; 95\% CI: 1.51-4.27).

Conclusion: these results may help the hospital and nursing managers to develop and implement strategies in order to reduce excessive demands and work overload and increase social support among the nursing staff.

DESCRIPTORS: Quality of life. Work. Burnout, professional. Nursing, team. Occupational health.

\section{ESTRESSE OCUPACIONAL E INSATISFAÇÃO COM A QUALIDADE DE VIDA NO TRABALHO DA ENFERMAGEM}

\section{RESUMO}

Objetivo: analisar a associação entre estresse ocupacional, qualidade de vida no trabalho e fatores associados a esta.

Método: estudo transversal, entre 309 trabalhadores de enfermagem de um hospital geral público. A qualidade de vida no trabalho e o estresse ocupacional foram avaliados, respectivamente, pelos instrumentos Total Quality of Work Life e Job Stress Scale.

Resultados: análise de regressão de Poisson com variância robusta evidenciou associação entre insatisfação com a qualidade de vida no trabalho e tabagismo ( $\mathrm{RP}=1,53$; IC95\%: 1,02-2,31), atuação em unidades de assistência a pacientes altamente dependentes ou críticos ( $R P=2$,47; IC95\%: 1,18-5,19), baixo apoio social no trabalho ( $R P=1,76$; IC95\%: 1,29-2,40) e os quadrantes do modelo demanda-controle "trabalho ativo" (RP=1,74; IC95\%: 1,04-2,92) e "alta exigência" (RP=2.54; IC95\%: 1,51-4,27).

Conclusão: estes resultados podem auxiliar as gerências hospitalares e de enfermagem no desenvolvimento e implementação de estratégias a fim de diminuir o excesso de demandas e sobrecarga laboral e aumentar o apoio social entre a equipe de enfermagem.

DESCRITORES: Qualidade de vida. Trabalho. Estresse ocupacional. Equipe de enfermagem. Saúde do trabalhador. 


\section{ESTRÉS OCUPACIONAL E INSATISFACCIÓN CON LA CALIDAD DE VIDA LABORAL DE ENFERMERÍA}

\section{RESUMEN}

Objetivo: analizar la asociación entre el estrés ocupacional, la calidad de vida laboral y los factores asociados a esta.

Método: estudio transversal entre 309 trabajadores de enfermería de un hospital público. La calidad de vida laboral y el estrés laboral fueron evaluados, respectivamente, por los instrumentos Total Quality of Work Life y Job Stress Scale.

Resultados: la regresión de Poisson con varianza robusta mostró asociación entre insatisfacción con la calidad de vida laboral y tabaquismo $(\mathrm{RP}=1,53$; IC95\%: 1,02-2,31), trabajo en los sectores para pacientes altamente dependientes o en estado crítico (RP=2,47; IC95\%: 1,18-5,19), bajo apoyo social ( $\mathrm{RP}=1,76$; IC95\%: 1,29-2,40) y los cuadrantes del modelo demanda-control "trabajo activo" (RP=1,74; IC95\%: 1,04-2,92) $\mathrm{y}$ "alta exigencia" ( $\mathrm{RP}=2,54$; IC95\%: 1,51-4,27).

Conclusión: estos resultados pueden ayudar a la gestión de los hospitales y de enfermería en el desarrollo e implementación de estrategias para reducir las demandas excesivas y la sobrecarga de trabajo y aumentar el apoyo social entre el equipo de enfermería.

DESCRIPTORES: Calidad de vida. Trabajo. Estrés laboral. Grupo de enfermería. Salud laboral.

\section{INTRODUCTION}

Studies have shown that nursing workers face more psychological distress than the general population, ${ }^{1-2}$ and are exposed to a variety of wear-generating elements. ${ }^{3}$ For this reason, their perceived work-related quality of life is a topic that has recently aroused increasing interest, in view of the importance of personal, environmental and organizational factors involved in the work context. ${ }^{4}$

A considerable number of nursing workers is inserted in hospitals, which often appear as institutions where the nursing management is not empowered, thus having no participation in making decision that influence the organization. In addition, the workers' work burden represents a barrier to the practice of this empowerment as, due to the lack of time in the daily practice of the nursing staff, direct patient care ends up being prioritized over organizational change initiatives and projects. ${ }^{5}$ That inevitably entails negative influence for the situation of workers, favoring increased demands and work overload even further, and consequently affecting the work-related quality of life.

There is no consensus on the concept of quality of work life (QWL), and there are various models to evaluate it. Among the classic models, the Walton model ${ }^{6}$ stands out, which states that the QWL emphasizes the needs and aspirations of human beings, as well as the social responsibility of the employee. This QWL approach emphasizes work as a whole, not being limited to address only the work environment itself, but mentioning the aspects of the non-work life. Like other approaches and concepts, however, the Walton model also has disadvantages, mainly in relation to the biologi$\mathrm{cal} /$ physiological sphere of the worker, which is hardly explored. ${ }^{7}$
There is already strong evidence about the inverse relationship between occupational stress among nursing workers and their perceived job satisfaction. ${ }^{8-10}$ However, QWL is a broader construct than job satisfaction and the former encompasses the latter. ${ }^{11}$ Some authors consider QWL as a construct that also involves other factors, such as the feeling of pride about the work performed, safety at work, ${ }^{12}$ recognition for the achieved results, perceived salary, human relationship within the group and the organization, work environment, freedom of choice, among others. ${ }^{13-14}$ Therefore, concentrating on only one feature of the work is an inappropriate approach to the evaluation of QWL. ${ }^{15}$

Literature has also pointed out important work attitudes and behaviors that may be affected by QWL, such as vigor, dedication, motivation, commitment, adaptability to changes in the work environment, creativity, desire to innovate and even influence the intent to stay or leave the organization/ profession. ${ }^{11-14,16}$

In spite of that, there are few research studies and analyses of QWL among nursing staff workers, which used validated instruments with satisfactory psychometric characteristics, especially in Brazil. Most of them use one-dimensional instruments with their own questions or scales or modified questionnaires by means of the combination of questions/ scales of other existing instruments. This paucity is most apparent with regard to the analysis of the association between occupational stress and QWL of nurses, nursing technicians and nursing assistants.

In this sense, considering that it is of fundamental importance to study and analyze the factors that affect the QWL of the nursing staff, this research aimed to analyze the association between occupational stress, QWL and associated factors among nursing staff. 


\section{METHOD}

This study is an excerpt from the research project entitled "Job conditions, health and quality of life of nursing workers", being characterized as a cross-sectional study, conducted at a large public hospital in the city of Jequié, in the State of Bahia, Brazil. The Hospital Geral Prado Valadares is characterized as one of the major regional referral hospitals, assisting the population of 25 cities.

Nurses, nursing technicians and nursing assistants working at the referred institution composed the study* population. The eligible participants also included the nursing workers who were off work due to some sort of license (premium, sick leave, pregnancy, personal interest etc.).

In total, 309 workers from the nursing team of 334 participated in the survey, representing a response rate equivalent to $92.5 \%$. The 25 losses $(7.5 \%)$ were due to refusals $(2.4 \%)$, non-return of the questionnaire $(1.5 \%)$ and impossibility to contact the participant $(3.6 \%)$.

This study followed the Brazilian recommendations on the ethical and bioethical principles of research involving human beings and received approval from the Ethics Research Committee of the State University of Southwest Bahia (CAAE 26737214.0.0000.0055).

Before the actual data collection, in February 2014, a pilot study was conducted among 20 nursing workers from a philanthropic hospital in the city of Jequié. This procedure allowed us to establish if the instruments could be satisfactorily understood and answered. Then, data were collected from March to June 2014 through the use of a standardized questionnaire, consisting of three blocks of questions, which the participants self-completed after signing the Informed Consent Form, guaranteeing anonymity and confidentiality of information. The participants were contacted spontaneously at their workplace after checking the work scales of each sector. For workers on leave, an appointment was made for a home visit. One of the authors performed all data collection procedures.

The first block, consisting of 29 questions, investigated the following variables: gender, age, marital status, number of children, whether the participant is the only family provider, professional category, time since graduation, graduate education, frequency of thinking about changing profession (later dichotomized in "rarely" to those who responded "never" or "rarely" and "often" to those who answered "sometimes", "often" or "daily"), hours of sleep a day, smoking, physical activity level ("sedentary" =less than 10 minutes of moderate or vigorous physical activity per week; irregularly active $=10-149$ minutes of moderate activity per week or 10-74 minutes of vigorous activity per week; active $=150-299$ minutes of moderate activity per week or 75-149 minutes of vigorous activity per week; very active $=300$ minutes or more of moderate activity a week or 150 minutes or more of vigorous activity per week), length of work in the institution, type of job contract, type of work sector, length of work in this sector, choice of sector, weekly work hours, work shift, perception of the number of people in the working scale (sufficient or insufficient), net monthly salary in the institution and the presence of another employment bond.

The second block was used to assess the QWL of the study population and relates to the Total Quality of Work Life - TQWL-42. It was developed and validated based on contemporary Brazilian culture and had its foundation on the classic theoretical models of QWL. ${ }^{17}$

The TQWL-42 is composed of 42 questions, using a Likert-type response scale (1-5). Forty of them are equally divided into five spheres, which are composed of branches, named aspects, which the questions are grouped in. The spheres are: Biological/Physiological (physical and mental disposition, work ability, health and social care services, rest time), Psychological/Behavioral (self-esteem, task significance, feedback, personal and professional development), Sociological/Relational (freedom expression, interpersonal relationships, autonomy, leisure time), Economic/Political (financial resources, extra benefits, working hours, job security) and Environmental/Organizational (working conditions, development opportunities, variety and task identity). The remaining two questions, in turn, represent the aspect "self-assessment of QWL", which is not inserted in any sphere. ${ }^{17}$

For the analysis of the results of the TQWL42 , on a scale ranging from 0 to 100, 50 was considered as the central value, ${ }^{17}$ and lower and higher values were characterized as dissatisfaction and satisfaction, respectively. Thus, the possible classifications were: unsatisfactory $(0-50)$ and satisfactory (50.01-100).

\footnotetext{
* In Brazil, nursing is divided into three categories: nurse, nursing technicians and nursing auxiliaries, being the highest level is a nurse, followed by technicians and auxiliaries. Translator's note.
} 
The Job Stress Scale-JSS (third block) was also used in its version adapted and validated to Portuguese. ${ }^{18}$ The JSS contains 17 questions on a Likert-type response scale (1-4), five of which evaluate psychological demand, six control over work (or "decision latitude") and six social support. Based on the dichotomization into high and low of the dimensions "demand" and "control", using the median scores as cut-off points, four categories of the demand-control model were established: low-strain job (high decision latitude and low psychological demand; a reference category representing the "ideal" situation), active job (high decision latitude and high psychological demand), passive job (low decision latitude and low psychological demand) and high-strain job (low decision latitude and high psychological demand). The dimension "social support" was also dichotomized, considering the median of the scores, classifying them as high or low. ${ }^{18}$

The study variables were presented as absolute and relative frequencies. The association between QWL (dependent variable), occupational stress (independent variable) and social support and sociodemographic, occupational and lifestyle characteristics (covariables) was measured using the Chi-square test or Fisher's exact test, significance being set at less than $5 \%$. For the magnitude of the association, the prevalence ratio (PR) was used as the association measure, with a respective confidence interval (CI) of $95 \%$.

To construct the multiple logistic regression model, the variables were selected that obtained probability test scores lower than 0.20 in the bivariate analysis. Next, these variables were checked using the likelihood ratio test, keeping those with values lower than 0.05 in the test. The adjusted PR according to the remaining variables was constructed based on the final model. That model was subsequently evaluated using the Hosmer-Lemeshow goodness of fit test $\mathrm{t}^{19}$ and graphically verified using the area under the curve of the Receiver Operating Characteristic (ROC). The adjusted PR and their respective $95 \% \mathrm{CI}$, in turn, were estimated using Poisson regression with robust variance, previously indicated for use in cross-sectional studies..$^{20} \mathrm{All}$ analyses were conducted using STATA statistical software, version 9 .

\section{RESULTS}

Of the 309 study participants, 119 (38.5\%) were nurses, 165 (53.4\%) nursing technicians and $25(8.1 \%)$ nursing assistants. Most of them were women (89\%), with average age of 38.8 years, married or with a partner $(70.2 \%)$, with child(ren) $(72.2 \%)$, with an average 13.4 years since graduation and 7.1 years of experience at the institution, with an effective job contract $(90.2 \%)$ and weekly workload of 30 work hours (73.8\%).

The study results showed that, among nursing workers, $27.9 \%$ had a low-strain job, $19.2 \%$ passive job, $32.1 \%$ active job and $20.8 \%$ high-strain job. $51.9 \%$ of workers perceived low social support from supervisors and coworkers.

Among nurses, the active job prevailed and, among nursing technicians and assistants, low-strain job and passive job, respectively. It is noteworthy, however, that more than half of the nurses and nursing technicians perceived their job as active or high-strain. As for the work sector, a gradation was noted in the frequencies of individuals in active and high-strain jobs, which are lower among those who worked in administrative sectors or support/indirect patient care and higher among those who worked in direct care sectors and emphasized in the care units for highly dependent or critically ill patients.

Among workers who perceived low social support at work, the active job category prevailed, while among those who perceived high social support, low-strain job predominated. The jobs considered as active were a majority among both genders, both marital situations, longer or shorter work experience at the institution and in the activity sector and among those who either have or do not have another job or paid work.

The overall prevalence of dissatisfaction with QWL was of $36.7 \%$ among the nursing staff. Table 1 shows the results of the bivariate analysis. At a significance level of $5 \%$, worse perception of QWL was more present among workers who often thought of changing profession ( $\mathrm{PR}=1.54 ; 95 \% \mathrm{CI}$ : 1.13-2.11; $\mathrm{p}=0.005)$, who slept seven hours or less per day ( $P R=1.42 ; 95 \% C I$ : 1.01-1.99; $p=0.036)$, who work in healthcare units for highly dependent or critically ill patients ( $\mathrm{PR}=2.96$; 95\%CI: 1.30-6.77; $\mathrm{p}=0.001$ ), who perceived low social support from coworkers and supervisors (PR=1.84; 95\%CI: 1.33 2.53; $\mathrm{p}<0.001)$, and those who perceived their job, according to the quadrants of the demand-control model, as active ( $\mathrm{PR}=2.40$; 95\% CI: 1.44-4.02; $\mathrm{p}<0.001)$ and high-strain $(\mathrm{PR}=3.36$; 95\%CI: 2.045.56; $\mathrm{p}<0.001)$. 
Table 1 - Prevalence (P\%), prevalence ratios (PR) and confidence intervals (95\%CI) of dissatisfaction with the quality of work life according to sociodemographic, lifestyle, professional and working characteristics among nursing workers. Jequié, Bahia, Brazil, 2014

\begin{tabular}{|c|c|c|c|c|}
\hline Variable/categories & $(\mathbf{P} \%)$ & $\mathbf{R P}$ & $95 \% \mathrm{CI}$ & p-value \\
\hline \multicolumn{5}{|l|}{ Gender } \\
\hline Male & 29.4 & 1.00 & & \\
\hline Female & 37.6 & 1.28 & $0.74-2.20$ & 0.351 \\
\hline \multicolumn{5}{|l|}{ Age } \\
\hline$>40$ years & 34.0 & 1.00 & & \\
\hline$\leq 40$ years & 37.9 & 1.12 & $0.81-1.54$ & 0.498 \\
\hline \multicolumn{5}{|l|}{ Marital status } \\
\hline Married or with a partner & 35.9 & 1.00 & & \\
\hline Single or without a partner & 38.5 & 1.07 & $0.78-1.47$ & 0.676 \\
\hline \multicolumn{5}{|l|}{ Number of children } \\
\hline 0 & 37.6 & 1.00 & & \\
\hline 1 & 37.3 & 0.99 & $0.67-1.47$ & 0.968 \\
\hline 2 & 37.4 & 0.99 & $0.68-1.44$ & 0.970 \\
\hline$\geq 3$ & 31.7 & 0.84 & $0.50-1.42$ & 0.514 \\
\hline \multicolumn{5}{|l|}{ Provides for the family alone } \\
\hline No & 37.1 & 1.00 & & \\
\hline Yes & 33.9 & 0.91 & $0.62-1.34$ & 0.633 \\
\hline \multicolumn{5}{|l|}{ Professional Education } \\
\hline Nursing technician/assistant & 33.3 & 1.00 & & \\
\hline Registered nurse & 42.0 & 1.26 & $0.94-1.69$ & 0.124 \\
\hline \multicolumn{5}{|l|}{ Time since graduation } \\
\hline$\geq 10$ years & 50.0 & 1.00 & & \\
\hline$<10$ years & 33.9 & 0.68 & 0.44-1.05 & 0.075 \\
\hline \multicolumn{5}{|l|}{ Graduate degree } \\
\hline Yes & 42.1 & 1.00 & & \\
\hline No & 32.6 & 0.77 & $0.58-1.04$ & 0.086 \\
\hline \multicolumn{5}{|c|}{ Frequency of thinking of changing profession } \\
\hline Rarely & 28.4 & 1.00 & & \\
\hline Often & 43.7 & 1.54 & $1.13-2.11$ & 0.005 \\
\hline \multicolumn{5}{|l|}{ Hours of sleep a day } \\
\hline$>7$ hours & 29.0 & 1.00 & & \\
\hline$\leq 7$ hours & 41.1 & 1.42 & 1.01-1.99 & 0.036 \\
\hline \multicolumn{5}{|l|}{ Tobacco } \\
\hline Never smoked & 35.4 & 1.00 & & \\
\hline Gave up smoking/smokes & 47.1 & 1.33 & $0.90-1.96$ & 0.183 \\
\hline \multicolumn{5}{|l|}{ Physical activity } \\
\hline Very active & 35.3 & 1.00 & & \\
\hline Active & 35.6 & 1.01 & $0.55-1.84$ & 0.981 \\
\hline Irregularly active & 27.5 & 0.78 & $0.39-1.54$ & 0.470 \\
\hline Sedentary & 39.2 & 1.11 & $0.68-1.81$ & 0.670 \\
\hline \multicolumn{5}{|l|}{ Time of work at the institution } \\
\hline$>5$ years & 37.3 & 1.00 & & \\
\hline$\leq 5$ years & 36.2 & 0.97 & $0.72-1.30$ & 0.842 \\
\hline \multicolumn{5}{|l|}{ Type of employment } \\
\hline Effective & 38.4 & 1.00 & & \\
\hline Contracted & 23.3 & 0.61 & $0.31-1.18$ & 0.104 \\
\hline
\end{tabular}




\section{Variable/categories}

Type of unit/sector

Differentiated/support/administrative services

Units for patients of intermediate or semi-critical care

Units for highly dependent or critically ill patients

Time of service in the sector

$$
\geq 3 \text { years }
$$$$
<3 \text { years }
$$

Possibility of sector choice

Yes

No

\section{Weekly working hours}

30 hours

40 hours

Work shift

Only daytime

Only overnight

Switches between day and night

Perception of the number of people in the working scale

Sufficient

Insufficient

Net salary of the institution

$\geq 3$ minimum wages

$<3$ minimum wages

Another job or paid work

No

Yes

\section{Demand-Control model}

Low-strain job

Passive job

Active job

High-strain job

\section{Social support at work}

High

Low
(P\%)

RP

$95 \% \mathrm{CI}$

p-value

$16.1 \quad 1.00$

$32.9 \quad 2.04$

$0.89-4.69$

0.063

$47.8 \quad 2.96$

1.30-6.77

0.001

$38.2 \quad 1.00$

$36.0 \quad 0.94$

$0.69-1.28$

0.703

$32.1 \quad 1.00$

$40.6 \quad 1.26$

$0.93-1.71$

0.126

$38.8 \quad 1.00$

$32.5 \quad 0.84$

0.59-1.19

0.314

$40.1 \quad 1.00$

$30.3 \quad 0.75$

0.53-1.08

0.118

$40.7 \quad 1.01$

$0.70-1.46$

0.944

$25.6 \quad 1.00$

$38.5 \quad 1.50$

$0.88-2.56$

0.103

$37.7 \quad 1.00$

$35.5 \quad 0.94$

$0.70-1.27$

0.694

$32.5 \quad 1.00$

$41.4 \quad 1.27$

$0.95-1.71$

0.107

$17.6 \quad 1.00$

$30.5 \quad 1.73$

$0.95-3.15$

0.071

$42.4 \quad 2.40$

1.44-4.02

$<0.001$

59.4

3.36

2.04-5.56

$<0.001$

$25.7 \quad 1.00$

$47.2 \quad 1.84$
In the final regression model, poor perception of QWL was statistically associated with work in sectors that provide care to highly dependent or critically ill patients (PR=2.47; 95\%CI: 1.18-5.19; $\mathrm{p}=0.017)$, the "active job" (PR=1.74; 95\%CI: 1.042.92; $\mathrm{p}=0.034)$ and "high-strain job" $(\mathrm{PR}=2.54$; 
Table 2 - Final regression model with prevalence ratios (PR), confidence intervals (CI) and respective p-values of dissatisfaction with life quality at work among nursing workers. Jequié, Bahia, Brazil, 2014

\begin{tabular}{|c|c|c|c|}
\hline Variable/categories & $(\mathbf{P} \%)$ & $95 \% \mathrm{CI}$ & p-value \\
\hline \multicolumn{4}{|l|}{ Tobacco } \\
\hline Never smoked & 1.00 & & \\
\hline Gave up smoking/smokes & 1.53 & $1.02-2.31$ & 0.042 \\
\hline \multicolumn{4}{|l|}{ Type of unit/sector } \\
\hline Differentiated/support/administrative services & 1.00 & & \\
\hline Units for patients of intermediate or semi-critical care & 1.78 & $0.84-3.76$ & 0.132 \\
\hline Units for highly dependent or critically ill patients & 2.47 & $1.18-5.19$ & 0.017 \\
\hline \multicolumn{4}{|l|}{ Work shift } \\
\hline Only daytime & 1.00 & & \\
\hline Only overnight & 0.73 & $0.52-1.03$ & 0.074 \\
\hline Switches between day and night & 0.96 & $0.68-1.34$ & 0.804 \\
\hline \multicolumn{4}{|l|}{ Demand-Control model } \\
\hline Low-strain job & 1.00 & & \\
\hline Passive job & 1.40 & $0.76-2.55$ & 0.277 \\
\hline Active job & 1.74 & $1.04-2.92$ & 0.034 \\
\hline High-strain job & 2.54 & $1.51-4.27$ & $<0.001$ \\
\hline \multicolumn{4}{|l|}{ Social support at work } \\
\hline High & 1.00 & & \\
\hline Low & 1.76 & $1.29-2.40$ & $<0.001$ \\
\hline
\end{tabular}

95\% CI: 1.51-4.27; $\mathrm{p}<0.001)$ quadrants of the demand-control model, as well as low social support perceived at work (PR=1.76; 95\% CI: 1.29-2.40; p $<0.001)$. Present or previous smoking $(\mathrm{PR}=1.53$; 95\% CI: 1.02-2.31; $\mathrm{p}=0.042)$, in turn, gained statistical significance in the multivariate analysis, and direct association with dissatisfaction with QWL (Table 2). The final regression model showed a p-value of 0.38 in the Hosmer-Lemeshow goodness of fit test, indicating that the observed frequencies are close to the expected frequencies. The final model also presented an area under the ROC curve of 0.75 , indicating acceptable discrimination ability.

\section{DISCUSSION}

The results of this study support the assumption which states that high-strain jobs would generate negative repercussions on the individual's health ${ }^{21}$ since higher prevalence of dissatisfaction with QWL was found among nursing workers who, in turn, noticed high psychological demands com- bined with low decision latitude. Other studies investigating the direct relationship between psychological demand, decision latitude and QWL were not found. Similar findings to those observed in the present study are found in the literature though, analyzing the outcomes job satisfaction, organizational commitment, psychological and structural empowerment $t^{22}$ and intent to stay or leave the profession, ${ }^{23}$ factors previously mentioned as associated or inherent to the investigation of QWL.

Also according to the premise of the demand-control model, work combining low decision latitude and low demand (passive job) are considered as inducers of decline in global activity of the individual and reduced ability to produce solutions to the activities and problems faced. That is so because the worker would be prone to an apathy state, either by absence of significant challenges and permission for performances with energy, or systematic rejection of their work initiatives. On the other hand, jobs considered active would provide motivation to develop new behaviors and 
learning, and a positive coping pattern under simultaneous conditions of high psychological demands and high decision latitude. ${ }^{21}$

Despite this hypothesis, nurses, nursing technicians and nursing assistants in active jobs had a higher prevalence of dissatisfaction with QWL than those in passive jobs; whereas these were not associated with worse perceived QWL compared to low-strain jobs. This demonstrates that even a high decision latitude, especially among higher education professionals, who have greater decision authority, sometimes are not able to suppress the negative aspects resulting from high demand, which is characterized mainly by disproportionality between the number of patients and nursing staff and the multiple jobs.

In addition, it is worth underlining the relationship between autonomy and responsibility, in which the increased responsibility, due to increased autonomy, can generate more workloads and more tension between workers. Thus, although decision latitude is theoretically a measure of autonomy and freedom for skills and qualifications use, in practice, it may also represent greater responsibility and pressure, which could have negative repercussions for workers. ${ }^{24}$

The perception of social support at work, an aspect later included in the demand-control model to evaluate social integration, confidence in the group and help from co-workers and supervisors to perform tasks, could act as a protective/buffering factor of the negative effects caused by high-strain jobs, ${ }^{21}$ a hypothesis that has already shown good evidence in the scientific literature., ${ }^{9,23,25}$

In this sense, a study carried out with nursing workers in Spain ${ }^{16}$ showed a close association between QWL and social support at work. Other studies have also revealed the relationship between social support and job satisfaction, motivation, work commitment and/or intent to leave the organization/profession..$^{23,25-29}$

Among the organizational obstacles that can impair the social relationships in the workplace, the following are highlighted: impoverishment and repetitiveness of tasks, lack of motivation and encouragement, poor integration between employees and the organization and the psychological impacts of poor management, which does not aim for a preventive and humanist policy. ${ }^{30}$

The literature has pointed out that the support from supervisors seems to be more important for nursing staff than the support from coworkers, ${ }^{27-29,31}$ the latter also being associated to job satisfaction. Nursing requires teamwork to provide quality care, and since social support is a coping strategy these workers often use, healthy working relationships are also important. ${ }^{31}$ Together with the support from coworkers and supervisors, the work recognition by the organization is also important. The perception that the organization supports and valuates the profession contributes to increase job satisfaction. ${ }^{32}$

Nurses, nursing technicians and nursing assistants who work in sectors focused on direct patient care showed higher prevalence of unsatisfactory QWL than those working in the sectors exclusively administrative or at support and indirect assistance services. This difference in prevalence was statistically significant, specifically for professionals working in hospitalization units for highly dependent or critically ill patients, such as the Operating Room, Medical Clinics, Neurological Clinics and Intensive Care Unit.

The action in these sectors is often linked to situations such as accelerated work pace, greater demand for physical exertion in patient care and need for reasoning speed and decision-making agility. Thus, work in these sectors can represent stressful situations for the nursing worker, contributing to the occurrence of problems such as occupational stress, ${ }^{33}$ and musculoskeletal disorders, ${ }^{34-35}$ events that can have a negative impact on physiological, psychological, relational and organizational spheres, which constitute QWL.

Despite the low prevalence of smokers and former smokers $(11 \%)$ in this study, smoking was associated to the analyzed outcome, with those who smoke or have smoked showing a higher prevalence of dissatisfaction with QWL compared to individuals who have never smoked. In order to explain this association, it is worth mentioning anxiety as a possible articulating element between occupational stress and QWL, since tobacco use has been described as a strategy used to decrease 
or control anxiety levels, as a kind of self-medication. ${ }^{36-37}$ Consequently, in very stressful situations causing anxiety, a trend towards tobacco use is observed as a way to calm and relax the individual.

The current study has limitations that should be considered when interpreting the results. The first of them relates to its cross-sectional design, which does not permit inferences about the causality of the observed associations. The generalization of findings is limited, since the data collection was restricted to a single hospital. Although the multidimensional nature of the instrument used to assess the QWL is a positive aspect of this study, the lack of consensus among researchers about QWL measuring methods must be considered, which has been a limiting factor to establish comparisons between the study results and the findings in the literature.

\section{CONCLUSIONS}

In summary, this research found a positive association between dissatisfaction with quality of work life and smoking, work in the care units for highly dependent or critically ill patients, low social support at work and job considered as active and high-strain. These findings support the hypothesis that quality of work life is preserved in situations where the psychological demands are maintained at acceptable levels, while in situations in which these demands are high (such as stressful, anxiety-generating ones, in which there is a predominance of work overload, accelerated work pace or low social support), the negative repercussions for the nursing workers would be only mitigated, but not eliminated, by a high decision latitude.

The results of this study may help the hospital and nursing managers to develop and implement strategies in order to reduce the excessive demands and increase decision latitude and social support at work among the nursing staff.

\section{REFERENCES}

1. Karanikola M, Giannakopoulou M, Mpouzika M, Kaite CP, Tsiaousis GZ, Papathanassoglou EDE. Dysfunctional psychological responses among Intensive Care Unit nurses: a systematic review of the literature. Rev Esc Enferm USP. 2015 Oct; 49(5):847-57.

2. Cheung T, Yip PS. Depression, anxiety and symptoms of stress among Hong Kong nurses: a cross-sectional Study. Int J Environ Res Public Health. 2015 Sep; 12(9):11072-100.

3. Silva SM, Baptista PCP, Felli VEA, Martins AC, Sarquis LMM, Mininel VA. Intervention strategies for the health of university hospital nursing staff in Brazil. Rev Latino-Am Enfermagem. 2013 Jan-Feb; 21(1):300-8.

4. Kimura M, Carandina DM. Development and validation of a short form instrument for the evaluation of quality of working life of nurses in hospitals. Rev Esc Enferm USP. 2009 Dec; 43(spe):1044-54.

5. Van Bogaert P, Peremans L, de Wit M, Van Heusden D, Franck E, Timmermans $\mathrm{O}$, et al. Nurse managers' perceptions and experiences regardingstaff nurse empowerment: a qualitative study. Front Psychol. 2015 Oct; 6:1585.

6. Walton RE. Quality of working life: what is it? Sloan Manage Rev. 1973; 15(1):11-21.

7. Pedroso B, Pilatti LA. Notas sobre o modelo de qualidade de vida no trabalho de Walton: uma revisão literária. Conexões. 2009 Set-Dez; 7(3):2843.

8. Khamisa N, Peltzer K, Oldenburg B. Burnout in relation to specific contributing factors and health outcomes among nurses: a systematic review. Int J Environ Res Public Health. 2013 May; 10(6):2214-40.

9. Häusser JA, Mojzisch A, Niesel M, Schulz-Hardt $S$. Ten years on: A review of recent research on the Job Demand-Control (-Support) model and psychological well-being. Work Stress. 2010 Mar; 24(1):1-35.

10. Lu H, Barriball KL, Zhang X, While AE. Job satisfaction among hospital nurses revisited: a systematic review. Int J Nurs Stud. 2012 Aug; 49(8):1017-38.

11. Flores N, Jenaro C, Orgaz MB, Martín MV. Understanding quality of working life of workers with intellectual disabilities. J Appl Res Intellect Disabil. 2011 Mar; 24(2):133-41. 
12. Mosadeghrad AM. Quality of working life: an antecedent to employee turnover intention. Int J Health Policy Manag. 2013 May; 1(1):43-50.

13. Chiavenato I. Recursos humanos: o capital humano das organizações. $9^{a}$ ed. Rio de Janeiro (RJ): Elsevier; 2009.

14. Moreno A, Aranda C, Preciado M, Valencia S. Calidad de vida laboral en trabajadores de la salud, Tamaulipas, México 2010. Cienc Trab. 2011; 13(39):11-6.

15. Krueger P, BrazilK, Lohfeld L, Edward HG, Lewis D, Tjam D. Organization specific predictors of job satisfaction: findings from a Canadian multisite quality of work life cross-sectional survey. BMC Health Serv Res. 2002 Mar; 2:6.

16. Jenaro C, Flores N, Orgaz MB, Cruz M. Vigour and dedication in nursing professionals: towards a better understanding of work engagement. J Adv Nurs. 2011 Apr; 67(4):865-75.

17. Pedroso B, Pilatti LA, Gutierrez GL, Picinin CT. Construção e validação do TQWL-42: um instrumento de avaliação da qualidade de vida no trabalho. Rev Salud Publica (Bogota). 2014 Dez; 16(6):885-96.

18. Alves MGM, Chor D, Faerstein E, Lopes CS, Werneck GL. Versão resumida da "job stress scale": adaptação para o português. Rev Saude Publica. 2004 Abr; 38(2):164-71.

19. Hosmer DW, Lemeshow S, Sturdivant RX. Applied logistic regression. 3rd ed. New York: John Wiley \& Sons; 2013.

20. Coutinho LMS, Scazufca M, Menezes PR. Methods for estimating prevalence ratios in cross-sectional studies. Rev Saude Publica. 2008 Dec; 42(6):992-8.

21. Karasek R, Theorell T. Healthy work: stress, productivity and the reconstruction of working life. New York: Basic Books; 1990.

22. Laschinger HK, Finegan J, Shamian D, Almost J. Testing Karasek's demands-control model in restructured healthcare settings: effects of job strain on staff nurses' quality of work life. J Nurs Adm. 2001 May; 31(5):233-43.

23. Chiu YL, Chung RG, Wu CS, Ho CH. The effects of job demands, control, and social support on hospital clinical nurses' intention to turn over. Appl Nurs Res. 2009 Nov; 22(4):258-63.

24. Araújo TM, Graça CC, Araújo E. Estresse ocupacional e saúde: contribuições do Modelo Demanda-Controle. Cien Saude Colet. 2003; 8(4):991-1003.

25. McGilton KS, Hall LM, Wodchis WP, Petroz U. Supervisory support, job stress, and job satisfaction among long-term care nursing staff. J Nurs Adm. 2007 Jul-Aug; 37(7-8):366-72.

26. Bond MA, Punnett L, Pyle JL, Cazeca D, Cooperman M. Gendered work conditions, health, and work outcomes. J Occup Health Psychol. 2004 Jan; 9(1):28-45.

27. Gelsema TI, van der Doef M, Maes S, Akerboom $\mathrm{S}$, Verhoeven C. Job stress in the nursing profession: the influence of organizational and environmental conditions and job characteristics. Int J Stress Manag. 2005 Aug; 12(3):222-40.

28. Gelsema TI, van der Doef M, Maes S, Janssen M, Akerboom S, Verhoeven C. A longitudinal study of job stress in the nursing profession: causes and consequences. J Nurs Manag. 2006 May; 14(4):289-99.

29. Rodwell J, Munro L. Relational regulation theory and the role of social support and organisational fairness for nurses in a general acute context. J Clin Nurs. 2013 Nov; 22(21-22):3160-9.

30. Ferreira RC. Apoio social no trabalho e absenteísmo-doença em trabalhadores de enfermagem [dissertação]. Rio de Janeiro: Universidade Federal do Rio de Janeiro, Escola de Enfermagem Anna Nery, Programa de PósGraduação em Enfermagem; 2010.

31. Gelsema TI. Job stress in the nursing profession [doctoral dissertation]. Leiden: Leiden University; 2006.

32. Bradley JR, Cartwright S. Social support, job stress, health, and job satisfaction among nurses in the United Kingdom. Int J Stress Manag. 2002 Jul; 9(3):163-82.

33. Schmidt DRC, Dantas RAS, Marziale MHP, Laus AM. Estresse ocupacional entre profissionais de enfermagem do bloco cirúrgico. Texto Contexto Enferm. 2009 Abr-Jun; 18(2):330-7. 
34. Reed LF, Battistutta D, Young J, Newman B. Prevalence and risk factors for foot and ankle musculoskeletal disorders experienced by nurses. BMC Musculoskelet Disord. 2014 Jun; 15:196.

35. Magnago TSBS, Lisboa MTL, Griep RH, Kirchhof ALC, Camponogara S, Nonnenmacher CQ, et al. Nursing workers: Work conditions, socialdemographic characteristics and skeletal muscle disturbances. Acta Paul Enferm. 2010 Mar-Apr; 23(2):187-93.
36. Carceller-Maicas N, Ariste S, Martínez-Hernáez A, Martorell-Poveda MA, Correa-Urquiza M, DiGiacomo SM. El consumo de tabaco como automedicación de depresión/ansiedad entre los jóvenes: resultados de un estudio con método mixto. Adicciones. 2014; 26(1):34-45.

37. Pietras T, Witusik A, Panek M, Szemraj J, Górski P. Anxiety, depression and methods of stress coping in patients with nicotine dependence syndrome. Med Sci Monit. 2011 May; 17(5):CR272-6. 